Sport Humanities

\title{
Gazeta do Norte newspaper and the great Sports Square as nation projects: 'Mold for Tomorrow's Men!'
}

\author{
Rogério Othon Teixeira Alves ${ }^{1}$ (D), Luciano Pereira da Silva ${ }^{2}$ (D), Ester Liberato Pereira ${ }^{1}$ (D), \\ Georgino Jorge de Souza Neto ${ }^{1}$ D, ${\text { Fernanda de Souza } \text { Cardoso }^{1} \text { (D), Carlos Rogério Ladislau }}^{1}$ \\ ${ }^{1}$ Universidade Estadual de Montes Claros, Montes Claros, MG, Brasil; ${ }^{2}$ Universidade Federal de \\ Minas Gerais, Belo Horizonte, MG, Brasil. \\ Editor: Angelina Zanesco, Universidade Estadual Paulista "Júlio de Mesquita Filho", Instituto de \\ Biociências, Departamento de Educação Física, Rio Claro, SP, Brasil.
}

\begin{abstract}
Aim: This study contextualizes the establishment of Montes Claros Sports Square, in Minas Gerais, through the look of Gazeta do Norte newspaper, and its alignment with a nation project to be established by the government of Getúlio Vargas, who took office in 1930. He formulated actions for a 'national reconstruction' project, for which, from society, it was necessary to emerge both physically and morally healthy subjects, fundamental conditions for the construction of the aforementioned new nation, and which could reach the Brazilians in the hinterlands. Thus, this study aimed to narrate a history of the construction of Montes Claros Sports Square, from the end of the 1930s until 1945, during Getúlio Vargas' first term as President of the Republic, with Benedito Valadares as Governor of Minas Gerais. Methods: The study was based on the extensive collection of data researched in Gazeta do Norte newspaper. Results: Symbol of a modern project for sports, the Sports Square was announced by the governor during his visit to the city, in January 1939, and established on the Oswaldo Cruz meadow. It is possible to verify that, notably, in the 15 years of Getúlio Vargas' first term, the practice of sports is developed and consolidates itself as an 'actor' in the social space of Montes Claros. Conclusion: In this city, in addition to the construction of the Sports Square, it was necessary to educate and inform the individuals. It can be said that the newspaper Gazeta do Norte firmly contributed to Vargas' nation project.
\end{abstract}

Keywords: Gazeta do Norte, Sports Square, nation, history, sport.

\section{Introduction}

The period of social distancing, motivated by the COVID19 pandemic in 2020 , became a special time for each citizen to reflect on personal and professional aspects. Invariably, adopting a new discourse, and envisioning a different future, have been products of the quarantine miasmas.

During the period of social distancing imposed by the new coronavirus, some political and social discussions were raised about the authority to be followed by the population in times of a pandemic: there are defenders of the health authority as a driver and defenders of the opening of trade as a fundamental axis of society. In this scenario, health was on the agenda.

Questioning health is nothing new; be it in primary access to the hospital network, or in basic education to live healthily, it has been running through the backstage of political power for a long time. In Brazil, it is no different. In this sense, historically, the efforts of the government of Getúlio Vargas in the implementation of policies for the development of bodily health of Brazilians are known, with hygienist and eugenicist policies that aimed at dis- ciplining and shaping the body of the 'new' Brazilian, an orderly citizen, imbued with civic values and physically well prepared. However, the question is: at that time, how to remove the image of Jeca Tatu from Brazilians? Monteiro Lobato's character, '[...] is a caboclo with a thin beard, that is, a mestizo; without property and education, a countryman; who lives in the shadows of civilization and ignores what is happening in the country; he is completely unaware of his rights and duties ${ }^{1}$. Government intervention in health was challenging, given the continental size of the country and the social inequality among its citizens.

As for public health policy, what initiates a practical project, whatever the moment? Regarding the beginning of the twentieth century, in Brazil, the provocative speech given by professor Miguel Pereira in 1916, and published by the press of the time, entitled: 'Brazil is still a huge hospital $^{2}$. In it, the physician explains the weaknesses of Brazilians from the hinterlands, individuals abandoned and forgotten by the political authorities, unable to stand up to fight for the nation, due to numerous diseases that affected them. The explanation made by Pereira would have an objective effect. 
In spite of the protests, from the aforementioned speech made by Pereira against the politicians and the health policy of the time, the theory had moved on to a more profound practice of health actions, over time. This is because, after the repercussion of the speech by the professor, in Brazil, it would be noted the '[...] role of physicians in the creation of health policies in the following years, and so it was seen, even at the time and, later, by historiography who took care of it ${ }^{3}$.

The government of Getúlio Vargas, who took office in 1930, in addition to burying the 'coffee with milk' policy, the symbol of the first phase of the Brazilian Republic, formulated a project for a 'national reconstruction'. From society, individuals, men, and women, healthy physically and morally, had to emerge, fundamental conditions for the construction of such new nation, and which could reach the more inland Brazilian. In this process, school physical education and gymnastics should be protagonists. Finally, as stated by Soares ${ }^{4}$ : 'The discourse and medical practice in their hygienist conceptions, with a strong moralizing, normative and adaptive/educational character, constituted instruments of intervention in society'.

Based on this idea, the construction of social sports spaces became part of the formulation of public policies by governments. In the state of Minas Gerais, the government planned and built sports squares in some cities, one of them in Montes Claros, considered one of the most important cities in the state, which had its Sports Square construction started in 1939 and was officially opened in 1944. By being the main city hub of northern Minas Gerais ${ }^{5}$, since ' $[\ldots]$ the end of the 19 th century, Montes Claros was already considered the main urban and commercial center of the northern region of Minas Gerais ${ }^{2}$.

Based on the extensive collection of data researched in the newspaper Gazeta do Norte, this study aimed to narrate a history of the construction of the Montes Claros Sports Square, from the late 1930s to 1945, during the first term of Getúlio Vargas, as President of the Republic, and Benedito Valadares, as Governor of Minas Gerais. Simultaneously with the history, it aimed to analyze the use of the Sports Square as a construct of the idea of the official formulation of a new notion of health, aimed mainly at young people.

\section{Method}

The choice of newspapers as a source was because '[...] the essence of journalism is the information of the day, that is, of facts, situations, and ideas that are occurring, unfolding or acting in and about a certain community in the precise moment of their manifestation' 7 . The daily life recorded in the newspapers can demonstrate the human being living in collectivity and, from these, it is possible to explain the lifestyle habits of a remote society, not only by the so-called 'illustrious' individuals but also by the citizens considered less important or anonymous.

In the newspapers researched, the purpose was to make use of the exploration of indicative paradigms based on the semiotic analogy indicated by Ginzburg ${ }^{8}$, like a hunter who, in order to chase and capture his prey, sticks to almost invisible details, 'He learned to sniff, record, interpret and classify infinitesimal tracks, like beard threads'. Or, as Bloch ${ }^{9}$ warned about historical observation, 'the knowledge of all human facts in the past, most of them in the present, must be knowledge through traces'. For this reason, the news, reports, and images about the design, construction, and use of the large Sports Square were identified and organized according to the proposed objectives, notably those related to the eugenic and hygienic ideas propagated by the Vargas government for young people, in order to make the analysis possible.

The place for collecting information in the Montes Claros newspaper was the Regional Research and Documentation Center (CPDOR) of the State University of Montes Claros (Unimontes), with restricted and regulated public access. In this archive, observing the research period, Gazeta do Norte was the most important and most widely circulated newspaper in the city. Founded in 1918, Gazeta do Norte was published weekly until the 1930s, when it became biweekly until the 1960s when it stopped being published. Thus, it became the most accessed source.

\section{Results and Discussion}

\section{The great Sports Square: cradle of a new generation!}

Symbol of a modern project for sports, the Sports Square was announced by the governor of the state of Minas Gerais, Benedito Valadares, during his visit to the city, in January 1939, and established in the Oswaldo Cruz meadow. From it, it is noted that the political discourse linked to sports was more evident in the reports of Gazeta do Norte, and modern sports practices were based on the equipment of the new sports square.

\footnotetext{
Montes Claros will soon have a magnificent sports square that will be one of the largest and best in the state. Governor Benedito Valadares, in his recent stay in our city, authorized the construction of a large sports field, which will be located in the Oswaldo Cruz meadow and will include a splendid swimming pool, a football stadium with grandstands, volleyball, tennis and basketball courts, and a children's pool ${ }^{10}$.
}

The large Sports Square was justified due to the political appeal and, also, due to the political strategy, assumed by the government of Getúlio Vargas, imposing, to the physical activities, ends extended to them, as a means for the conquest of health and the acquisition of the purity of the Brazilian race. 
Regarding these purposes, it should be noted that Gazeta do Norte was also a vehicle for dissemination. This intention of the journal can be seen in an article published on the matter in 1940 . Written by a military physician from Montes Claros for the magazine "Educação", from Rio de Janeiro, he narrated that he was dedicated to the expansion of physical education in Brazil, highlighting the moral, hygienist, and eugenicist functions that such practices would have on individuals:

The distinguished medical lieutenant of Montes Claros, writing about medicine and physical education, approached the problem elegantly and interestingly, highlighting the practice of sport and athletism as decisive factors for the purity of the race, not only under the physical but also moral and intellectual aspects, emphasizing the role of the physician who adopts sport, even as an elevated means of health and eugenics ${ }^{11}$.

Before its inauguration, in the light of the 1940s of the New State of the Vargas era, what was expected in the future project was published in Gazeta do Norte. These are reports that denote the grandeur of the facilities, the pride that the city should feel, the change and the formation of a generation of strong and invincible citizens of Montes Claros: "This week, the services of the majestic sports square that will be built by the State in our city and which will be built on the Oswaldo Cruz meadow have started"12.

Today, thanks to the honorable spirit of accomplishment of our illustrious Mayor, the old Oswaldo Cruz meadow it is already worthy of an honorable visit because it shows a long step towards our progress. It is there that it appears, rising majestic, beautiful, and imposing, it is an elegant and modern sports square or better, the concretization of a noble word, fulfilled for the good of a people who work and deserve. Thanks to this brilliant achievement, no one will be able to say that Montes Claros is a land without entertainment and even without Sundays. [...] And even more, in the future, a strong and happy generation will march supported by the care that will soon be provided to them. And if that generation does not neglect itself, it will have a powerful weapon at hand to be strong and invincible ${ }^{13}$.

Gazeta do Norte, in its reports about modern sports, propagated the idea of the incursion of new life habits with which the population should adapt. As is well known, most sports are 'imported', so it is conjectured that learning or simply having news about their rules and characteristics was something that the newspaper was already doing constantly. Such new customs would reflect a 'modern way' and, thus, adherence to this lifestyle could be seen in the placement of advertisements in the newspaper, for example.

Probably, due to this 'sports' social scenario that was installed, it is that the American company Gillette, in an advertising campaign in the 1940s and 1941 (entitled 'Sport - Health Factor'), often occupying an entire page of Gazeta do Norte, in order to offer its product, linked the presentation of a sport to what its product could, supposedly, offer to the buyer. The company, which is still active today, as a landmark, says it was the first to bet on sports marketing and the male consumer when, in 1910, it associated its brand with famous baseball players from the United States.

In Gazeta do Norte, it is clear that Gillette wanted to sell its shaver by aligning it with the modern man through sport. As a marketing strategy, when using jiu-jitsu (Figure 1), basketball (Figure 2), boxing, volleyball, swimming (Figure 3), athletics, golf, football, and rowing, at the same time, promoted notions of health, hygiene, and civility by advertising in the newspaper. The spread of sports themes in Gazeta do Norte, exploited by a commercial bias, indicated how much sports had already penetrated a portion of society, through the press, what seemed unlikely in previous years.

According to Thaís Meinicke ${ }^{14}$, in Rio de Janeiro, one of the centres that radiated the principles of modernity in Brazil, '[...] sports games were blessed by medical organizations, who started to preach their practice to the press and the families'. When sports were seen as possible promoters of civility and order, they started to have greater importance for people. In the former federal capital, '[...] these physical activities quickly became part of the prescription for a "civilized" life, a type of life that was fashionable in the $1920 \mathrm{~s}$, with its practitioners known as sportsmen, ${ }^{14}$.

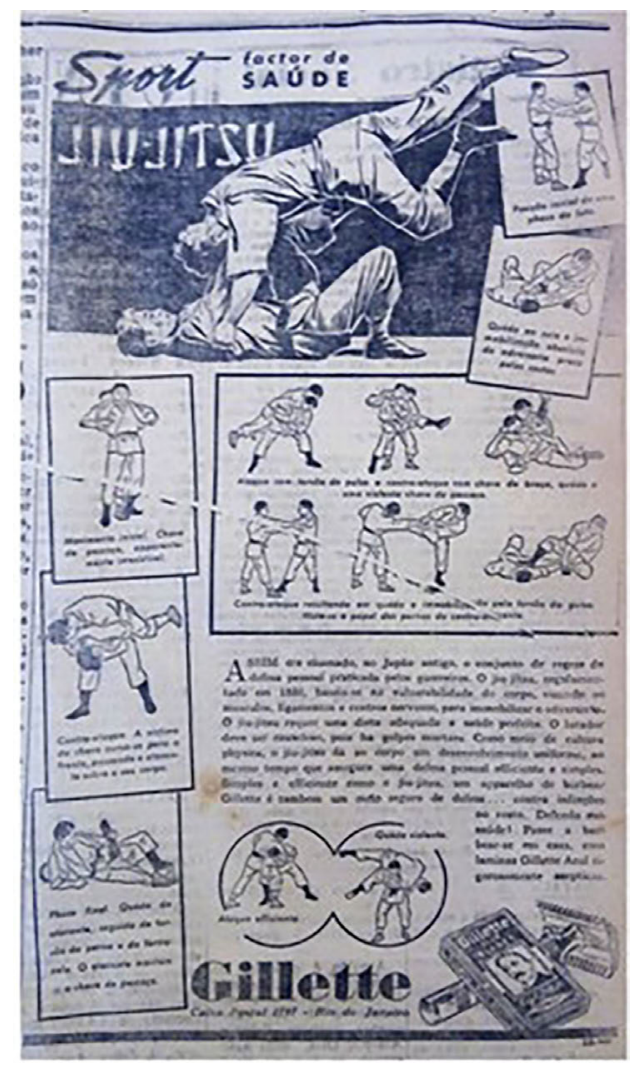

Figure 1 - Gillette advertisement featuring jiu-jitsu. Source: Gazeta do Norte (Minas Gerais). Saturday, 22 June 1940, p. 3. 


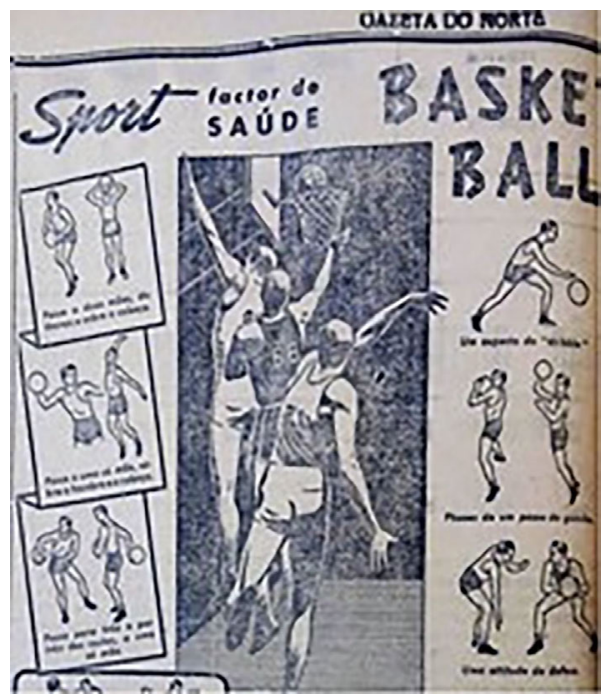

Figure 2 - Gillette advertisement featuring basketball. Source: Gazeta do Norte (Minas Gerais). Saturday, 8 October 1941, p. 3.

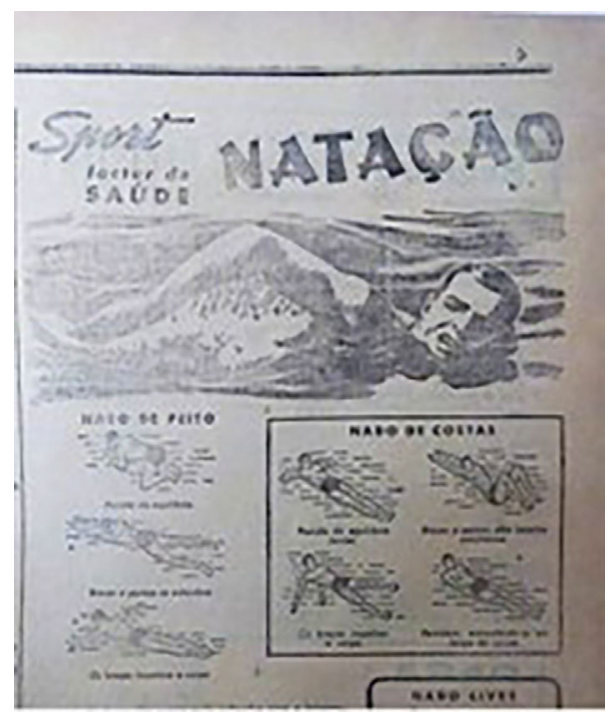

Figure 3 - Gillette advertisement featuring swimming. Source: Gazeta do Norte (Minas Gerais). Saturday, 20 December 1941, p. 5.

In the late 1930s and early 1940s, reporting on sports events and practices became more frequent on the pages of Gazeta do Norte. At that time, during the celebrations of the tenth anniversary of the New State, politics and sports were increasingly more associated, linked by the interest of social penetration that modern physical practices produced: 'In celebration of the 10th of November, the tenth anniversary of the New State, the city will attend several sports events, in a civic-sports party that already has the support of the Mayor, the city clubs and society in general, with the income obtained destined to the works of the new Cathedral $^{15}$.

As they became popular, even if especially with the elite of the city, the newspaper would explore the topic in its sports sections. This characteristic of the press was already observed, in Rio de Janeiro, since the beginning of the 20th century. In the Federal Capital, well before Montes Claros, '[...], variety magazines include sports as an example of healthy life in their agendas and newspapers are forced to report on the competitions and tournaments that took place in the city ${ }^{\prime 14}$.

One of the novelties of the Sports Square, which was still under construction in 1940, was its swimming pool. However, the advent of this equipment led to the preparation of people for its use, because there were no pools in sports associations until then, and educating young people to practice swimming was a challenge. In this process, $\mathrm{Mr}$. José Laércio de Oliveira stood out who, in addition to being responsible for the sports section of Gazeta do Norte, provided the society with information about the future of the sport in the pool, even before its inauguration. His knowledge came from the Minas Tennis Club (MTC), a sports organization in the state capital:

\footnotetext{
Next Monday, he will travel to the state capital, where he will receive his diploma from the Swimming Course instituted by the Minas Tennis Club, our distinguished fellow and well-known sportsman José Laercio de Oliveira, to whom the direction of the sports session of this newspaper is entrusted. The swimmer de Montes Claros, who obtained flattering approvals in that course, will teach swimming in our pool in the Sports Square ${ }^{16}$.
}

It is important to stress that providing the training of professionals to work in other locations within the state was the responsibility of Minas Tennis Club, a public policy instituted under the government of Benedito Valadares. The experimental inauguration of the pool in the sports square was (Figure 4), according to José Laércio de Oliveira, the founding landmark of the new club. For the sports columnist of Gazeta do Norte, the equipment would be the symbol of a new sports season in Montes Claros. And the young people should thank the governor and the mayor: 'The starting point for a new sporting season is set in Montes Claros! The experimental inauguration of our swimming pool last Sunday constitutes the most sensational sporting note of our day ${ }^{17}$.

José Laércio de Oliveira, through Gazeta do Norte, was a spokesman for the benefits that sports could promote, as he advocated being the square: 'Cradle of a new generation! Mold for tomorrow's men!'. It should be noted that his posture was in line with the governmental political precepts in vogue in the country. The forging of a new generation of Brazilians, he said, would be achieved through ' $[\ldots]$ modern sport [...] based on medicine, pedagogy, and psychology'. Anyway, at that moment, the Sports Square could form ' $[\ldots]$ intelligent and moralized men, developing $[\ldots]$ the triple education: physical, moral and intellectual ${ }^{18}$.

The sensitization of the population, strategically promoted by Gazeta do Norte, seeking to arouse the interest of future sportsmen, promoting modern progressive 


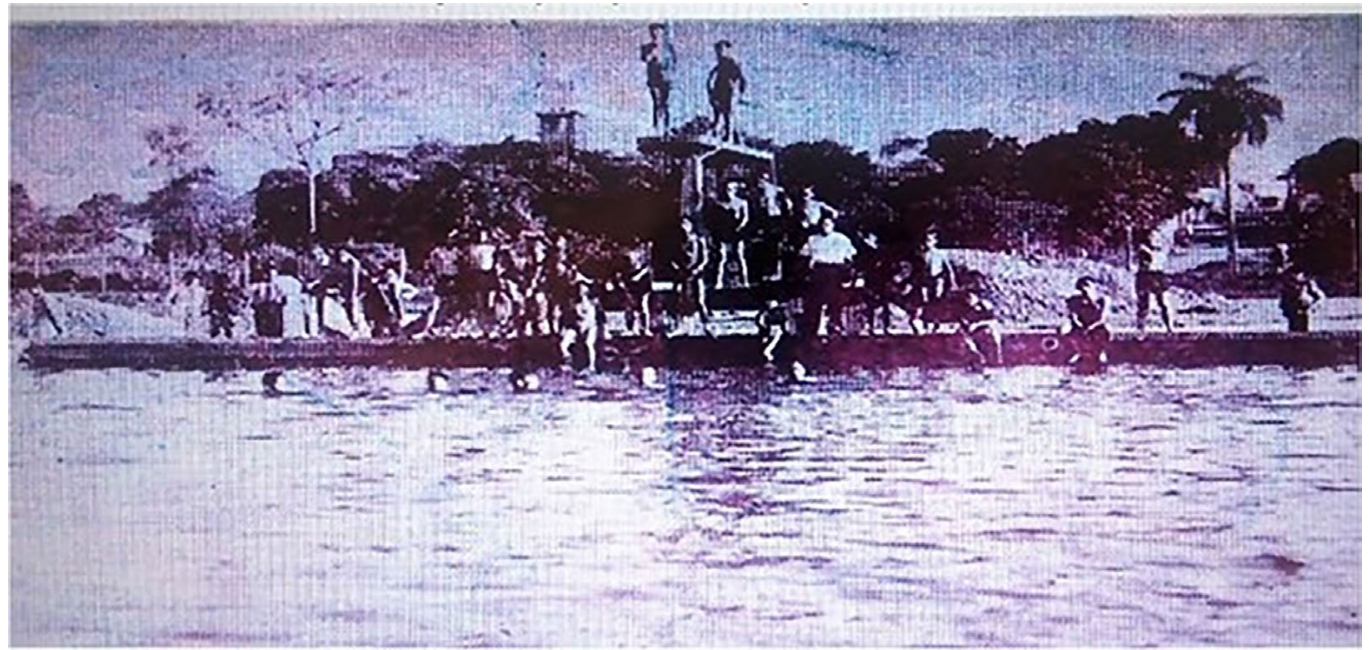

Figure 4 - The Sports Square pool in 1940. Source: Revista Montes Claros (Minas Gerais), No. 2, October 1940, page 36.

and civilizing purposes through the practice of physical education and sports, would assist in the use of the new equipment. This, built by the government of the state of Minas Gerais, was assigned to the Montes Claros Club, with mediation from the municipality.

Thus, the constitution of the management of the Sports Square followed political and also social procedures, since, in addition to being assigned to a social club in the city by the Mayor, with the consent of the Governor, it should compose '[...] the plan state, in favour of the development of sports in the country. In this way, supposedly, Montes Claros would solve [...] the problem of the physical education of its children, ${ }^{18}$.

When seeing the region of Montes Claros, in the hinterland and detached from the great centres of the nation, the reflection of what happened in the Capital is observed, radiating to the upstate city. In this analysis, we evaluate the warning made by Dias ${ }^{19}:$ ' $[\ldots]$ a research on the history of sports in some rural region in the countryside tends to reproduce, sometimes even in an exaggerated way, the same general conclusions of studies conducted in large urban centres'. However, it is identified that Minas Tennis Club, from Belo Horizonte, did, in fact, influence the design and execution of the Montes Claros Sports Square (Figure 5), playing a reference role.

Namely, the Minas Tennis Club (MTC) was designed along the same ideological lines as the Montes Claros Sports Square, however, it was built a few years earlier. Founded in 1935, what subsidized the club of the state capital were the same policies for the expansion of sports culture enacted by the government of Getúlio Vargas.

The great enterprise '[...] "Montes Claros Tennis Club" or "Minas Gerais Sports Square of Montes Claros" had its official inauguration in 1942. It cost public coffers '[...] more or less, one thousand and two hundred million réis, more than nine hundred from the Municipality and the rest from the State'. 'It is a very pleasant place, looking more like a large garden with some sports fields ${ }^{20}$.

Thus, there is that the beginning of the 20th century, in the country, is marked by a series of episodes that directed attention to the body ${ }^{21}$. Goellner ${ }^{22}$ articulates that the current speeches, in this time frame, listed the bodily and sports practices as activities for the improvement of the 'white and pure' race. In this way, the promotion of health and well-being was identified as 'absolutely tied to the nationalist policy in vogue based on eugenics and hygienism ${ }^{22}$ through, for example, new customs and new sports entertainment.

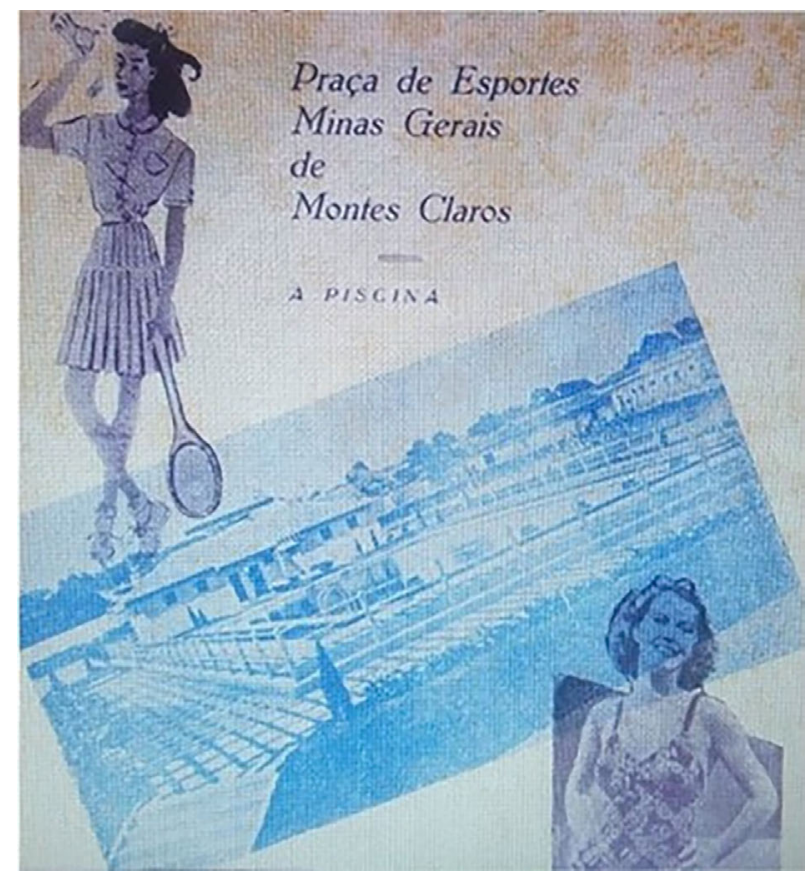

Figure 5 - Advertisement of the Sports Square in 1941. Source: Revista Montes Claros (Minas Gerais), No. 5, November 1941, p. 12. 
New sports, new customs: behaviour transformations intended through the use of the Sports Square

With Sports Square in operation, it is assumed that the enthusiasm would be immediate. However, contrary to the assumption, shortly afterward, the sensation found is one of losing interest. The new customs would not take root automatically. Although the process of consolidating modern practices in the Square is characteristic of the 'invented tradition' theory by Hobsbawn ${ }^{23}$, because we notice rules and norms aiming at new behaviours through sport, its establishment would occur in the midst of tensions.

As a result, Gazeta do Norte manifested itself against what it decreed as the abandonment of basketball and volleyball by the city. In addition to denouncing the phase of reduced activity of both sports, it explains the reasons for the issue, making it clear that, although the sports equipment is the first-rate, in the days of the old Montes Claros Atheneum and Sports and Athletics Association (AMEA), nostalgic associations that obeyed the guidance of a true sporting youth and that were always rivals in the field of struggle, there was more sporting 'life' ${ }^{24}$.

And this would not stop there. The annexations of the two main sports associations with the Sports Square, Atheneum, and Montes Claros Sports and Athletics Association, previously articulated by the mayor, according to Gazeta do Norte, would have been the main causes of the decay of local basketball and volleyball. When imposing a selected team in the Square, disinterest would be caused by the empty routine of unreasonable training that, in addition, the sportsman should pay for access to the courts, and not everyone could. Finally, for the newspaper, 'This is the main factor for the abandonment of its courts. Train? For what? To face who? To defend which club? $[\ldots]$ There is no incentive, there is no rivalry and there has been little interest in the boys in defending the colours of the Square ${ }^{25}$.

Thus, the year 1943 would end with a focused effort in holding a basketball championship, organized by the Basketball Department at the Montes Claros Tennis Club, with the participation of teams from the Montes Claros Tennis Club, Father Osmar Sports Club, and Northern Minas Gerais Education Institute ${ }^{26}$. Regarding the event, Gazeta do Norte observed that ' $[\ldots]$ the number of people who attended was small, showing little enthusiasm, perhaps due to the little dissemination of basketball and its rules ${ }^{27}$. The champion would be the team from the Northern Minas Institute ${ }^{28}$.

In the history of sport in Montes Claros, in 1943, Gazeta do Norte formulated justifications for the low attendance of members at the Sports Square, particularly mentioning the decline in volleyball and basketball. Some of them were: inadequate monthly fees for some members, the merger of the old sports associations with the new club, lack of teams for matches, and the absence of the rivalry factor. Possibly, due to this scenario, the mayor, in an interview with Gazeta do Norte, in January 1944, defended the purposes of the Sports Square, which supposedly accompanied ' $[\ldots]$ the pace of growing progress of the city', suggested a picture that did not exist about the 'impressive' attendance of sportsmen, and demonstrated to be aware of the objectives of national eugenic public policies of Vargas, '[...] everything under medical control, guidance and training of capable, experienced technicians, ${ }^{29}$.

The optimism of the mayor did not affect practice. The non-performance of activities in the Square, as expected, led to the resurgence of the Atheneum in 1944. The allegations for the return of the old club were based on the claims that sports were not for everyone, and that they demanded the factor of rivalry, aspects that existed before its construction. Finally, ' $[\ldots]$ the beautiful Sports Squares [...] constitutes a heritage that enchants our senses, but that, unfortunately, is, in reality, an embalmed being: without a soul, without enthusiasm, without life ${ }^{30}$.

In this scenario of discouragement and severe criticism, in order to summarize the reasons for the loss of interest in sports, which started right after the construction of the Square, the director of the Northern Minas Gerais Education Institute, in an interview for Gazeta do Norte, concluded at the time that, between the strangeness of the new equipment by the possible sportsmen, retracted by the pride of the most 'connoisseurs' of sports, and the unprecedented cement courts, terrible consumers of sports shoes and human meat, Montes Claros, in this sector, does not live the era of Physical Education:

\footnotetext{
The withdrawal of the youth, in relation to Sports Square, in my view, is bad for the unfortunate initial orientation. There was on the part of those who first said they were sports advisers there, a very great egoism to the point that the teams who went there to play or even train had stones thrown at them. [...] One of the advantages, also pointed out against the Square, is related to its cement fields, terrible consumers of sports shoes, and human meat. As you have noticed, the Square has so far been considered a rival sports team, an opponent, which is a huge mistake. It should be the point of preference for games or training for teams that do not have a field ${ }^{31}$.
}

Aside from the impression of behaving like 'frightened country boys', in the face of the transformations in behaviour and control imposed by the modern Sports Square, such as the rules for their use, another question would be asked: How to enjoy the equipment if the opening hours were during the day? It was the way of life of the boiling modern individual reflected in sports: '[To] our boys who are, or students, or businessmen, or bankers, or railroaders, it is not possible to constantly leave the responsibilities of their daily work, in order to, in good number, dedicate themselves to the practice of Physical Education within the established hours $[\ldots]^{32}$. From this 
observation, the practice of sports should obey the social time of Montes Claros, that is, only after getting rid of daily obligations, such as work or study, would the individual be able to engage in another activity willingly. Thus, the division of the daily routine would involve organizing the citizen's time in times for work, leisure, and rest, which are striking aspects of modern capitalist societies.

When observing these characteristics, a new board of Sports Square decided to have night lighting on one of its courts in 1944. In addition to observing the reduced attendance to the Square, what justified this investment was the understanding coming from sports clubs in more developed cities, as, 'Even in the large centres of the country, the same situation is observed. Both in Rio de Janeiro and Belo Horizonte, not to mention, there is more movement in the clubs at night, because their opening hours make them more accessible to everyone, ${ }^{32}$. In this understanding, attentive to what was happening in clubs in other cities, the club also adapted itself to the time available to members to the night practice. Official data on the number of visitors to the Sports Square would only be released by the club's board of directors as of 1945 onwards. 'Although it was created a long time ago, the Department of Physical Education did not report any movement, which only occurred in December' 1944. In addition to the practitioners of sports, members in general, and visitors, there were 61,068 regulars in $1944^{32}$.

In addition to the infrastructure, the new board reinforced the functionalist aspect of sports supported by Vargas, affirming the eugenic doctrine in the formation of a robust citizen, in search of order and progress. There was encouragement and stimulation in sports, in comprehensive physical education. 'And so, today's youth, under the norms of modern education, has been making the most fervent and sincere praises resonate, for such a happy and efficient initiative, ${ }^{, 33}$.

The finding of the relevance of sports and eugenics in the formation of citizens, on the front page of Gazeta do Norte, was ambiguous. At the same time that it boasted the policy adopted by the government of Getúlio Vargas when supposedly disseminating a new conception of physical education in the country, it sought to leverage the use of the Sports Square of the city, which suffered from the low attendance by the citizens of Montes Claros: 'With this collaboration, those who have the most profit today are young people, who, strengthened by well-guided physical exercises, may for the future present themselves for the struggle of life with the hygiene characteristic of strongmen. Our Sports Square is not just a centre for amusement. The reach it aims for is much higher. This extends to a simultaneous education of both physical and psychic aspects $^{34}$.

In this way, youth, as well as education, was chosen, since '[...] they play an important role in shaping the identity of a Nation-State: they ensure that a new genera- tion is committed early to the identity of society and that the number of disloyal people is "naturally" reduced" ${ }^{35}$. In such a way, this young social fraction would be adequate to demonstrate, in patriotic manifestations, in recreational activities and in sports practices, the civic devotion, the intellectual advance, and the physical energy that Vargas government hoped to insert into the daily customs of the Brazilian population $^{36}$.

Under the direction of Lauro Vicente Dias de Sá, sports activities were boosted in the second half of 1945 . This director of the Physical Education Department at the Sports Square, in addition to organizing an excursion for matches in the city of Diamantina ${ }^{37}$ and reorganizing the matches and championships of volleyball ${ }^{38}$ and basketball ${ }^{39}$ at the Square, was aware of the legal support necessary for the development of political guidelines for incentive to sports practice. In fact, to observe in the Federal Constitution document, in force since 1937, the laws that based the creation of a specialized technical body to accomplish the project of physical, intellectual, and moral training for young Brazilians:

The Magna Carta, granted in 1937, is a reflection of this formidable movement, whose objective was to make everything in Brazil great, including man. And the map of the Brazilian land is gradually endowed with specialized administrative bodies and technical institutes for the training of physical development instructors, the foundation of the intellectual and moral formation of the Childhood and Youth of Brazil ${ }^{40}$

After the end of the first government of Getúlio Vargas (1930-1945) and the beginning of a democratic period in Brazil, a time when the population control policy lost its strength, Gazeta do Norte, a newspaper founded in 1918 and which had passed through the two Great World Wars, as it rearranged itself in the face of national political discontinuities, began a new phase in the sports coverage of Montes Claros. From this, if the local sports were, for years, anchored in the eugenic, hygienic, and military justifications for its implantation and development, from 29 October 1945, the date of deposition of Vargas, it would gradually establish itself as an instituted social practice.

\section{Conclusion}

It is possible to verify that, notably, in the 15 years of the first government of Getúlio Vargas, sport is developed and consolidates itself as an 'actor' in the social space of Montes Claros. From this historical understanding, of the binomial sport and society, we can understand that it is impossible to imagine what the world would be like today, without the presence of sports. Perhaps, today, sports do not have the characteristics intended by hygienists and eugenicists of the first half of the 20th century. What the physicians intended was to mold the individual in favour of a nation that suffered from widespread endemics in the countryside. In that scenario, medical knowledge subsidized and justified the investment in actions that pro- 
pelled the physical and moral development of the weakened Brazilian youth. In Montes Claros, in addition to the construction of the Sports Square, it was necessary to educate and inform the citizens. Thus, the partnership between the press and health was fundamental, as it provided not only the dissemination of the practice of modern sports but also provided the citizen with supposedly civilizing basic knowledge for the modification of the physique.

The introduction of new habits would produce tensions generated by the clash between tradition versus modernity. Sports and gymnastics did not have the religious connotation of old forms of entertainment and use of free time related to the church, they, in spite of religion, were intended to act on the body, transforming the youth's physique to leverage the patriotic pride of the Brazilian citizen. It can be said that the newspaper Gazeta do Norte contributed firmly to this project of a nation by Vargas.

\section{References}

1. Moreira LS. Jeca Tatu: Um personagem composto por questões sociais. Juiz de Fora. Monografia [Graduação em Ciências Sociais] - Universidade Federal de Juiz de Fora; 2010.

2. Jornal do Commercio. Rio de Janeiro. 1916; October 11: 4.

3. Sá DM. A voz do Brasil: Miguel Pereira e o discurso sobre o "imenso hospital". Hist. cienc. saude-Manguinhos. 2009;16 (1):333-48.

4. Soares CL. Notas sobre a educação no corpo. Educ. rev. 2000; 16: 43-60.

5. Carvalho MEF. Língua e cultura do norte de Minas: a toponímia do município de Montes Claros. Belo Horizonte. Dissertação [Mestrado em Língua e Literatura] - Universidade Federal de Minas Gerais; 2010.

6. Lopes, VSVBV. Impactos da privatização na gestão de pessoas: um estudo de caso em empresa do setor de transporte ferroviário de carga de Montes Claros-MG. Belo Horizonte. Dissertação [Mestrado em Administração] - Universidade Federal de Minas Gerais. 2000.

7. Beltrão L. Jornalismo interpretativo. Ed. Sulina, Porto Alegre (RS), 1980.

8. Ginzburg C. Mitos, emblemas, sinais: morfologia e história. Ed. Companhia das Letras, São Paulo (SP), 1989.

9. Bloch M. Apologia da história ou: o ofício de historiador. Ed. Zahar, Rio de Janeiro (RJ), 2001.

10. Gazeta do Norte. Montes Claros. 1939; January 7: 1.

11. Gazeta do Norte. Montes Claros. 1940; November 30: 3.

12. Gazeta do Norte. Montes Claros. 1939; April 15: 1.

13. Gazeta do Norte. Montes Claros. 1940; June 8: 3.

14. Farias TDM. Imprensa esportiva carioca: modernizações e segmentação: um estudo de caso sobre o diário Lance. Rio de Janeiro. Monografia [Graduação em Jornalismo] - Universidade Federal do Rio de Janeiro; 2009.

15. Gazeta do Norte. Montes Claros. 1940; November 2: 3.

16. Gazeta do Norte. Montes Claros. 1940; July 27: 3.
17. Gazeta do Norte. Montes Claros. 1940; August 4: 3.

18. Gazeta do Norte. Montes Claros. 1940; August 31: 3.

19. Dias C. Esportes nos confins da civilização: Goiás e Mato Grosso, 1866 - 1936. Ed. 7 Letras, Rio de Janeiro (RJ), 2018.

20. Paula HA. Montes Claros: sua história sua gente seus costumes. Ed. Minas Gráfica, Belo Horizonte (MG), 1957.

21. Silva IM. Considerado de "utilidade pública" o Uberlândia Tênis Clube, dentro do notável programa traçado para o Estado pelo Governador Benedito Valadares: políticas públicas de esporte mineiras que incluíram a cidade Uberlândia (1943). Revista Três Pontos. 2015,12(2):68-76.

22. Goellner SV. "As mulheres fortes são aquelas que fazem uma raça forte": esporte, eugenia e nacionalismo no Brasil no início do século XX. Recorde: Revista de História do Esporte. 2008,1(1):1-28.

23. Hobsbawn E. A invenção das tradições. Ed. Paz e Terra, São Paulo (SP), 1997.

24. Gazeta do Norte. Montes Claros. 1943; July 11: 3.

25. Gazeta do Norte. Montes Claros. 1943; July 25: 3.

26. Gazeta do Norte. Montes Claros. 1943; December 12: 3.

27. Gazeta do Norte. Montes Claros. 1943; December 19: 2.

28. Gazeta do Norte. Montes Claros. 1944; August 27: 1.

29. Gazeta do Norte. Montes Claros. 1944; January 10: 3.

30. Gazeta do Norte. Montes Claros. 1944; August 10: 3.

31. Gazeta do Norte. Montes Claros. 1944; October 29: 3.

32. Gazeta do Norte. Montes Claros. 1944; October 5: 3.

33. Gazeta do Norte. Montes Claros. 1944; August 27: 1.

34. Gazeta do Norte. Montes Claros. 1944; October 19: 1.

35. Schrader A. Minorias étnicas na política educacional do Brasil: escolas de língua estrangeira nos anos 30 e 70 . Revista de Antropologia, 1986,29:99-112.

36. Dias GT. Cultura, política e alfabetização no Brasil: a 'Segunda Campanha de Nacionalização' do ensino (19381945). São Carlos. Dissertação [Mestrado em Ciências Sociais] - Universidade Federal de São Carlos; 2006.

37. Gazeta do Norte. Montes Claros. 1945; May 9: 2.

38. Gazeta do Norte. Montes Claros. 1945; June 3: 5.

39. Gazeta do Norte. Montes Claros. 1945; September 27: 3.

40. Gazeta do Norte. Montes Claros. 1945; June 7: 5.

\section{Corresponding author}

Ester Liberato Pereira. Universidade Estadual de Montes Claros, Campus Darcy Ribeiro, Rui Braga Avenue, Vila Mauriceia 39401-089, Montes Claros, MG, Brasil.

E-mail: ester.pereira@unimontes.br.

Manuscript received on April 21, 2021

Manuscript accepted on May 5, 2021

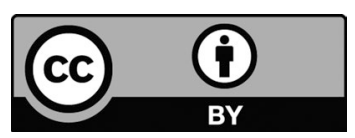

Motriz. The Journal of Physical Education. UNESP. Rio Claro, SP, Brazil - eISSN: 1980-6574 - under a license Creative Commons - Version 4.0 